Supplementary information (SI) for manuscript

\title{
Microbial Perchlorate Reduction Driven by Ethane and Propane
}

Chun-Yu Lai, Mengxiong Wu, Xuanyu Lu, Yulu Wang, Zhiguo Yuan, Jianhua Guo*

Advanced Water Management Centre, The University of Queensland, St Lucia, Brisbane,

Queensland 4072, Australia

* Correspondence to Dr Jianhua Guo. Tel: +61 73346 3222, Fax: +61 73365 4726, E-mail:

j.guo@awmc.uq.edu.au 
The PHA analysis method:

Biofilms were detached from the MBfR membranes for PHA analysis following 7 steps:

1) Each biofilm sample was freeze-dried and divided into three replicates.

2) Approximately $10 \mathrm{mg}$ of each biofilm sample was weighed and transferred into Hach tubes, and then $2 \mathrm{~mL}$ of $3 \%$ sulphuric acid in methanol and $2 \mathrm{~mL}$ of chloroform were added into each tube. Standards of pure PHB were treated similarly.

3) The tubes were tightly sealed with caps and digested at $100{ }^{\circ} \mathrm{C}$ for 20 hours.

4) After digestion, the samples were cooled to room temperature, and $1 \mathrm{~mL}$ of milli-Q water was added to each tube.

5) The samples were then vortexed and settled for 1 hour.

6) For each sample, $1 \mathrm{~mL}$ of liquid from the bottom phase was removed with a Pasteur pipette and transferred into a gas chromatography (GC) vial.

7) Five pieces of molecular sieve were added to each vial. The vials were capped and shaken, and PHB was analyzed by GC as soon as possible. 
Table S1. Operational strategies during the batch tests.

\begin{tabular}{cccccc} 
Batch & System & $\mathrm{ClO}_{4}^{-}$ & $\mathrm{C}_{2} \mathrm{H}_{6} / \mathrm{C}_{3} \mathrm{H}_{8}$ & $\mathrm{O}_{2}$ & Purpose \\
\hline $\mathrm{A}$ & MBfR & $\checkmark$ & $\checkmark$ & $\checkmark$ & To test whether $\mathrm{ClO}_{4}^{-}$reduction and $\mathrm{C}_{2} \mathrm{H}_{6} / \mathrm{C}_{3} \mathrm{H}_{8}$ consumption are concurrent \\
B & MBfR & $\checkmark$ & $\times$ & $\checkmark$ & To study $\mathrm{ClO}_{4}{ }^{-}$reduction without $\mathrm{C}_{2} \mathrm{H}_{6} / \mathrm{C}_{3} \mathrm{H}_{8}$ \\
$\mathrm{C}$ & MBfR & $\times$ & $\checkmark$ & $\checkmark$ & To study $\mathrm{C}_{2} \mathrm{H}_{6} / \mathrm{C}_{3} \mathrm{H}_{8}$ consumption without $\mathrm{ClO}_{4}^{-}$ \\
D & Serum bottles & $\checkmark$ & $\checkmark$ & $\times$ & To investigate $\mathrm{C}_{2} \mathrm{H}_{6} / \mathrm{C}_{3} \mathrm{H}_{8}$ consumption and $\mathrm{ClO}_{4}{ }^{-}$reduction without $\mathrm{O}_{2}$ \\
\hline
\end{tabular}


Table S2. Pearson Correlation analysis for the MBfR supplied with $\mathrm{C}_{2} \mathrm{H}_{6}$.

\begin{tabular}{|c|c|c|c|c|c|}
\hline & & $\mathrm{C}_{2} \mathrm{H}_{6}$ consumption rate & $\mathrm{ClO}_{4}{ }^{-}$consumption rate & bmoX copies & pcrA copies \\
\hline & $\begin{array}{c}\text { Pearson } \\
\text { Correlation }\end{array}$ & 1 & 0.504 & $.953^{*}$ & 0.053 \\
\hline & Sig. (2-tailed) & & 0.496 & 0.047 & 0.947 \\
\hline $\mathrm{ClO}_{6}$ consumption rate & $\begin{array}{c}\text { Pearson } \\
\text { Correlation }\end{array}$ & 0.504 & 1 & 0.742 & 0.794 \\
\hline & Sig. (2-tailed) & 0.496 & 0.742 & 0.258 & 0.206 \\
\hline bmoX copies & $\begin{array}{c}\text { Pearson } \\
\text { Correlation }\end{array}$ & $.953^{*}$ & 0.258 & 0.330 \\
\hline & Sig. (2-tailed) & 0.047 & 0.794 & 0.330 & 0.670 \\
\hline pcrA copies & $\begin{array}{c}\text { Pearson } \\
\text { Correlation }\end{array}$ & 0.053 & 0.206 & 0.670 & 1 \\
\hline
\end{tabular}

* Correlation is significant at the 0.05 level (2-tailed). 
Table S3. Pearson Correlation analysis for the MBfR supplied with $\mathrm{C}_{3} \mathrm{H}_{8}$.

\begin{tabular}{|c|c|c|c|c|c|}
\hline & & $\mathrm{C}_{3} \mathrm{H}_{8}$ consumption rate & $\mathrm{ClO}_{4}{ }^{-}$consumption rate & bmoX copies & pcrA copies \\
\hline & $\begin{array}{c}\text { Pearson } \\
\text { Correlation }\end{array}$ & 1 & 0.443 & $.995^{* *}$ & 0.038 \\
\hline & Sig. (2-tailed) & & 0.557 & 0.005 & 0.962 \\
\hline & $\begin{array}{c}\text { Pearson } \\
\text { Correlation }\end{array}$ & 0.443 & 1 & 0.474 & 0.761 \\
$\mathrm{ClO}_{4}{ }^{-}$consumption rate & Sig. (2-tailed) & 0.557 & 0.474 & 0.526 & 0.239 \\
\hline & $\begin{array}{c}\text { Pearson } \\
\text { Correlation }\end{array}$ & $.995^{* *}$ & 0.526 & & 0.119 \\
\hline \multirow{2}{*}{ bmoX copies } & Sig. (2-tailed) & 0.005 & 0.761 & 0.119 & 0.881 \\
\hline & $\begin{array}{c}\text { Pearson } \\
\text { Correlation }\end{array}$ & 0.038 & 0.239 & 0.881 & 1 \\
\hline
\end{tabular}

** Correlation is significant at the 0.01 level (2-tailed). 
A

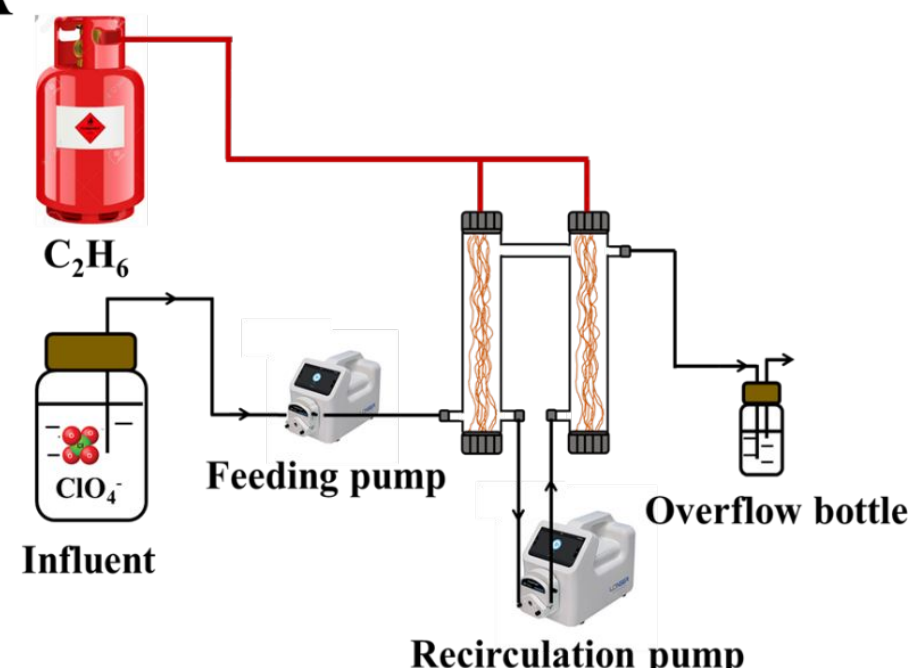

B

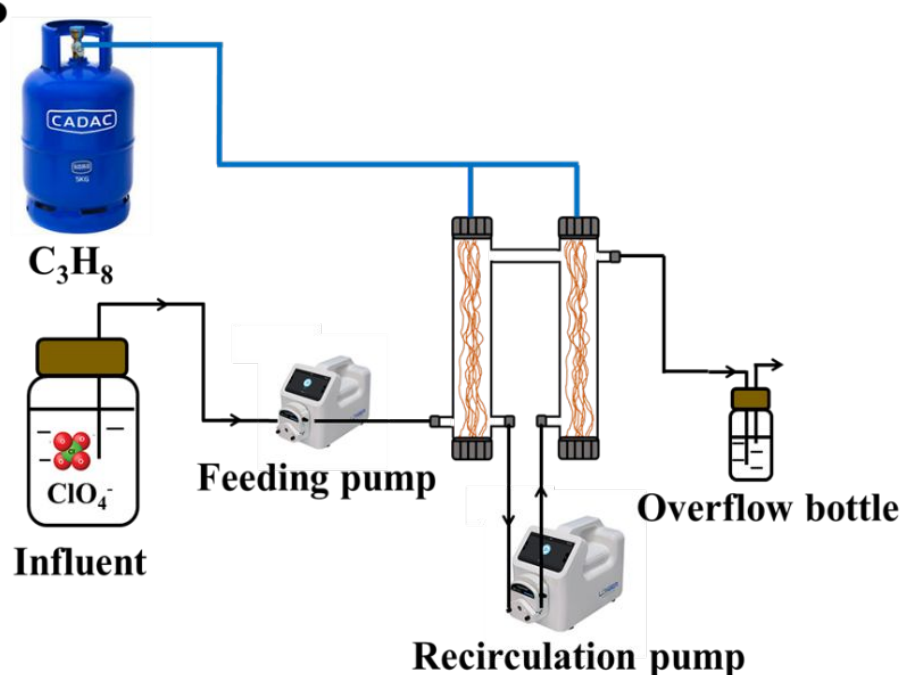

Figure S1. Schematic diagram of MBfRs supplied with $\mathrm{C}_{2} \mathrm{H}_{6}(\mathrm{~A})$ and $\mathrm{C}_{3} \mathrm{H}_{8}(\mathrm{~B})$, respectively. 

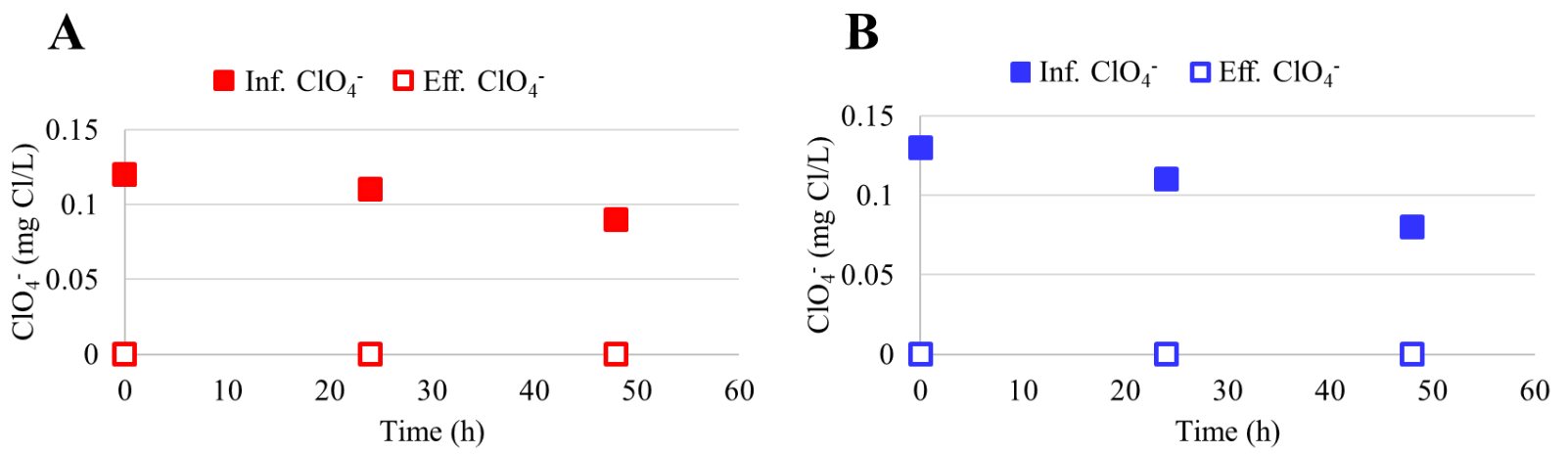

Figure S2. $\mathrm{ClO}_{4}^{-}$removal performance of two $\mathrm{MBfRs}$ feeding with $0.1 \mathrm{mg} \mathrm{Cl} / \mathrm{L}^{-} \mathrm{ClO}_{4}^{-}$in influent. $\mathrm{A}$ and $\mathrm{B}$ show the concentrations of influent $\mathrm{ClO}_{4}{ }^{-}$, and effluent $\mathrm{ClO}_{4}{ }^{-}$for $\mathrm{C}_{2} \mathrm{H}_{6}$ and $\mathrm{C}_{3} \mathrm{H}_{8}$ based MBfRs, respectively. 


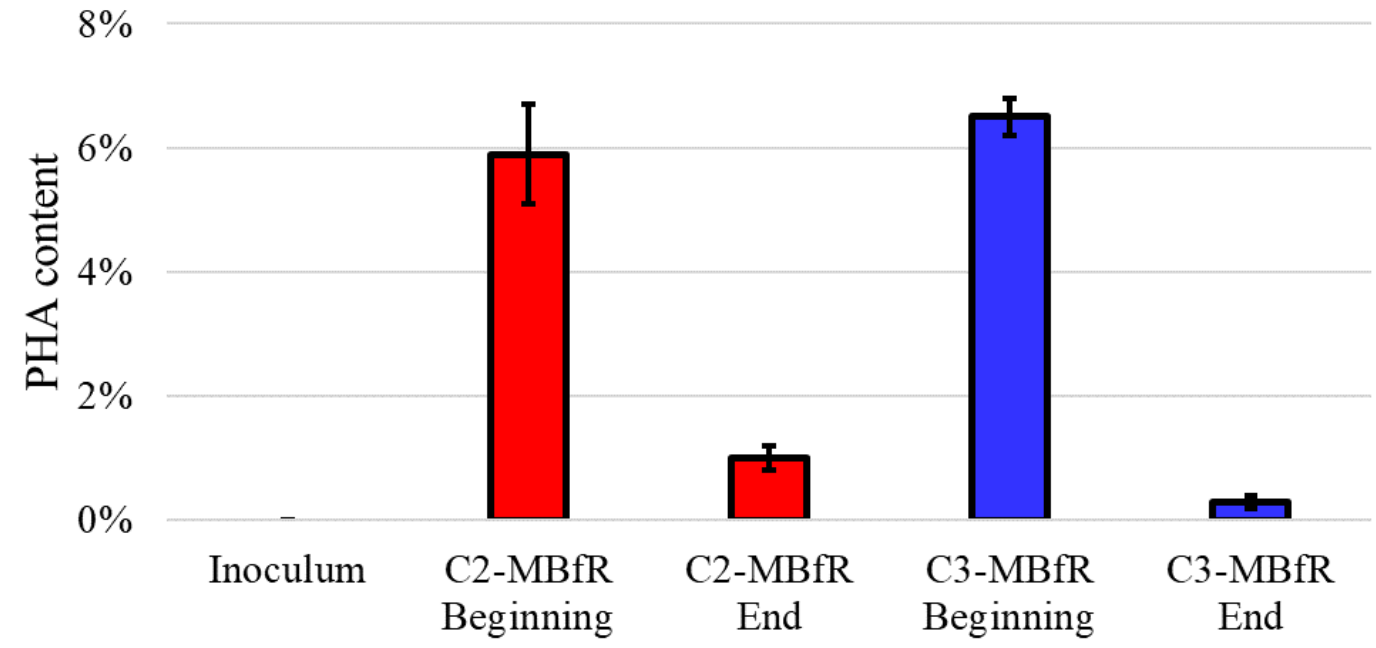

Figure S3. PHA content of the biofilms in the MBfRs during Batch test B. PHA content is defined as the percentage of the ratio of PHA weight to biomass dry weight. C2 and C3 indicate $\mathrm{C}_{2} \mathrm{H}_{6}$ and $\mathrm{C}_{3} \mathrm{H}_{8}$, respectively. 


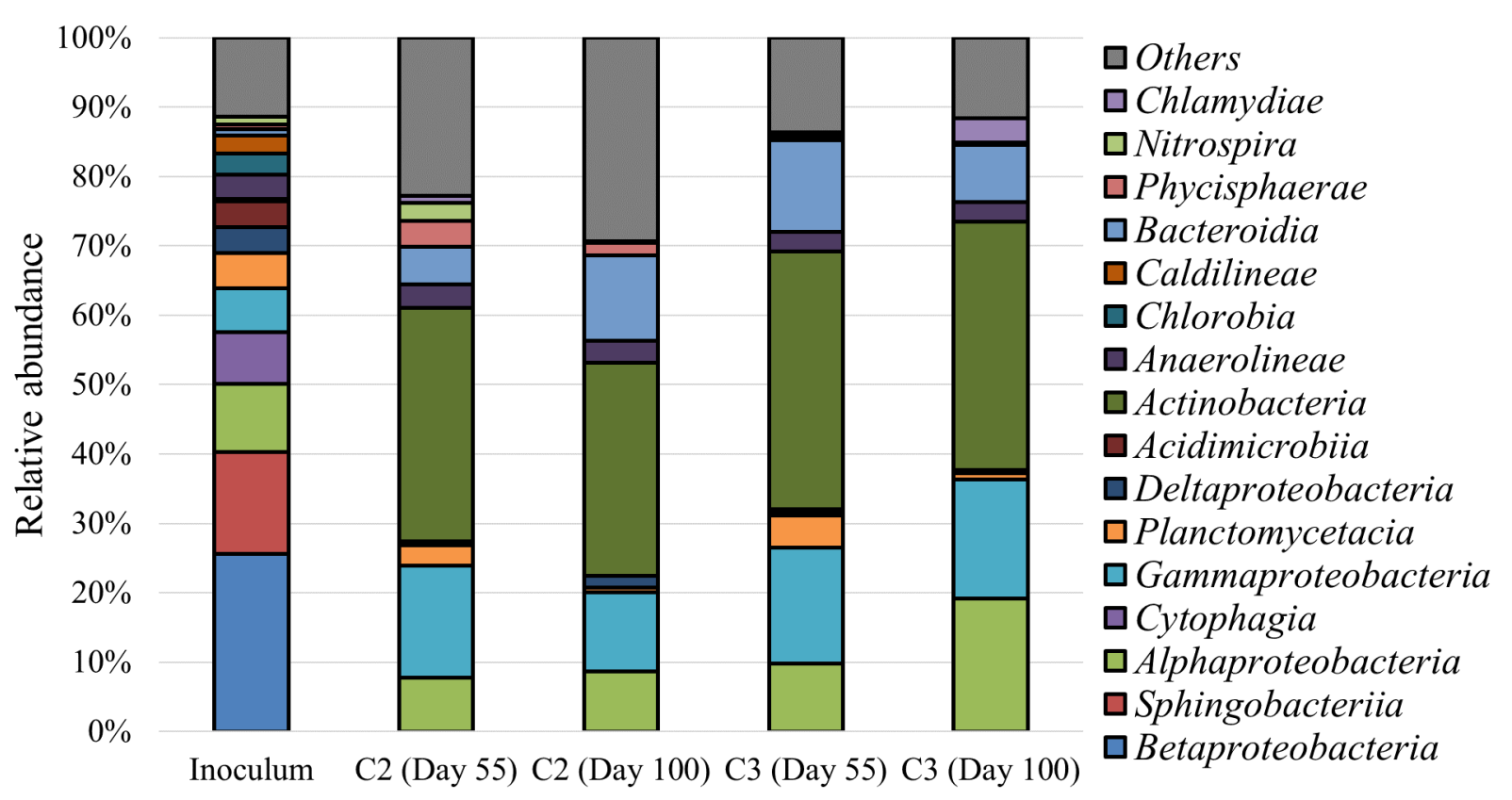

Figure S4. Relative abundance of dominating organisms in the respective MBfR inoculum and biofilm at class level. Class with an abundance $>2 \%$ in at least one sample is shown. 


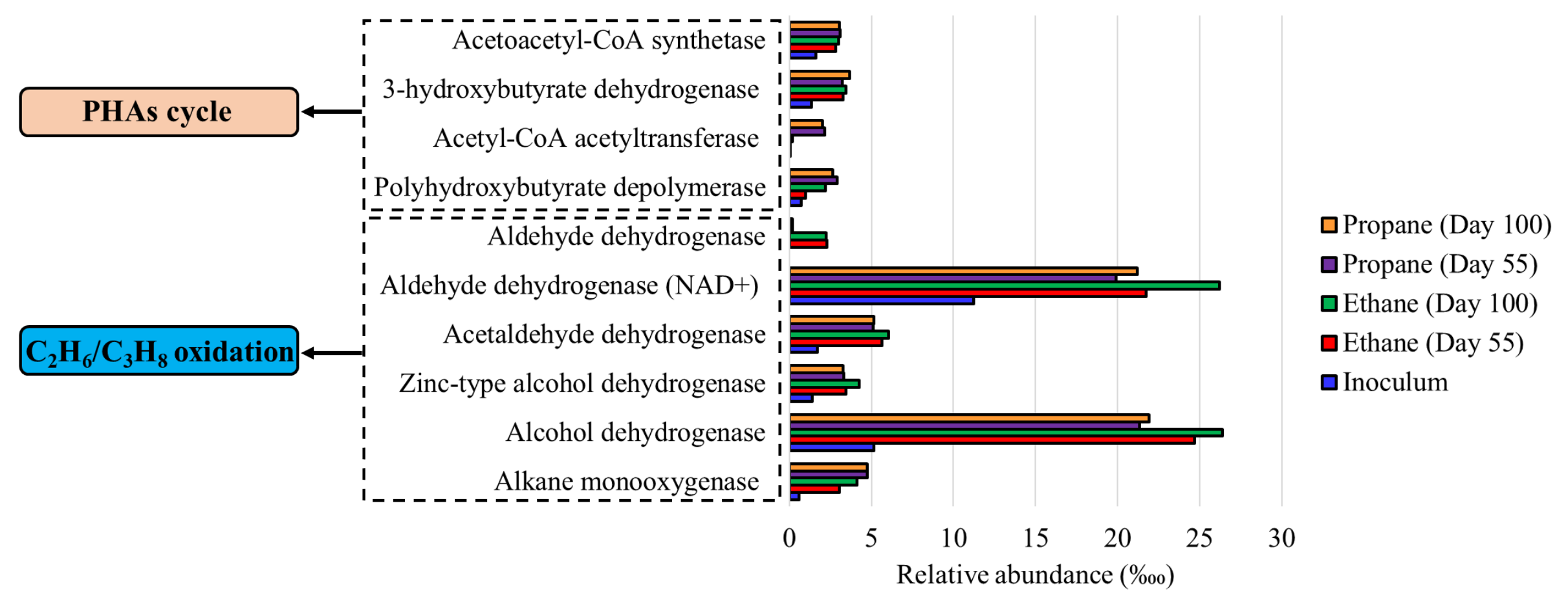

Figure S5. Predictive genes involved in alkane oxidation, perchlorate reduction and the PHAs cycle in the inoculum and biofilms of each MBfR. 